\title{
Evidence of precessional and eccentricity orbital cycles in a Tithonian source rock: The mid-outer carbonate ramp of the Vaca Muerta Formation, northern Neuquén Basin, Argentina
}

Diego A. Kietzmann, Javier Martín-Chivelet, Ricardo M. Palma, José López-Gómez, Marina Lescano, and Andrea Concheyro

\section{ABSTRACT}

Basin to mid-ramp cyclic facies of the Tithonian Vaca Muerta Formation are exposed in the Loncoche Creek section of the Neuquén Basin, Mendoza province, Argentina. This unit is characterized by a decimeter-scale rhythmic alternation of marls, shales and limestones and extends from the lower Tithonian to the upper Berriasian. Cyclostratigraphic studies based on a detailed facies analysis allowed the identification of cyclic patterns with frequencies within the Milankovitch band. According to biostratigraphic data, the dominant cycle in the studied section has a period of 20 k.y., which correlates with the Earth's axis precession element. Spectral analysis based on a series of compacted and decompacted cycle thick-ness identified a subordinate frequency of about 90 to 120 k.y., which we interpret as the modulation of the precessional cycle caused by the Earth's orbital eccentricity. The strength of the precession signal, together with the absence of a well-defined cyclicity attributable to the obliquity orbital cycle (i.e., $\sim 40$ k.y.), is in agreement with previous data from the Northern Hemisphere.

\section{AUTHORS}

Diego A. Kietzmann Departamento de Ciencias Geológicas, Facultad de Ciencias Exactas y Naturales, Universidad de Buenos Aires-Consejo Nacional de Investigaciones Científicas y Técnicas, Pab. 2, Ciudad Universitaria, 1428 Buenos Aires, Argentina; diegokietzmann@gl.fcen.uba.ar

Javier Martín-Chivelet Departamento de Estratigrafía, Instituto de Geología Económica-IGEO (CSIC-UCM), Facultad de Ciencias Geológi-cas, Universidad Complutense de Madrid, 28040 Madrid, Spain; j.m.chivelet@geo.ucm.es

Ricardo M. Palma Departamento de Cien-cias Geológicas, Facultad de Ciencias Exactas y Naturales, Universidad de Buenos Aires-Consejo Nacional de Investigaciones Científicas y Técnicas, Pab. 2, Ciudad Universitaria, 1428 Buenos Aires, Argentina; palma@gl.fcen.uba.ar

José López-Gómez Departamento de Estrati-grafía, Instituto de Geología Económica-IGEO (CSIC-UCM), Facultad de Ciencias Geológicas, Universidad Complutense de Madrid, 28040 Ma-drid, Spain; jlopez@geo.ucm.es

Marina Lescano Departamento de Ciencias Geológicas, Facultad de Ciencias Exactas y Natur-ales, Universidad de Buenos AiresConsejo Nacio-nal de Investigaciones Científicas y Técnicas, Pab. 2, Ciudad Universitaria, 1428 Buenos Aires, Ar-gentina; lescano@gl.fcen.uba.ar

Andrea Concheyro Departamento de Cien-cias Geológicas, Facultad de Ciencias Exactas y Naturales, Universidad de Buenos Aires-Consejo Nacional de Investigaciones Científicas y Técnicas, Pab. 2, Ciudad Universitaria, 1428 Bue-nos Aires, Argentina; andrea@gl.fcen.uba.ar 
We thank Robert G. Loucks, Brian P. Coffey, and an anonymous reviewer whose constructive com-ments improved the original manuscript. This research has been done under the framework of the UBACyT X-476 (Universidad de Buenos Aires) and PIP 5142 (CONICET) projects, as well as the research groups 910198 and 910429 (UCM-Comunidad de Madrid, Spain). We thank Alberto Riccardi (Universidad Nacional de La Plata y Museo, Argentina) for ammonite identification and Susana Damborenea (Universidad Nacional de La Plata y Museo, Argentina) for bivalve and brachiopod identification. To Luis Buatois and Gabriela Mángano (Saskatchewan University) for the identification of trace fossils. We thank Graciela Bressan for her help in the field. We thank J. C. Poblete for his hospitality and time shared with us. This is the contribution R-04 of the Instituto de Estudios Andinos Don Pablo Groeber.

The AAPG Editor thanks the following reviewers for their work on this paper: Brian P.Coffey, Robert G. Loucks, and an anonymous reviewer.

\section{INTRODUCTION}

Analysis of cycle stacking patterns in marine carbonate se-quences is a powerful technique for reconstructing relative sea level and cyclic climate changes in very different time scales, particularly those controlled by variations in the Earth's orbit at frequencies of $10^{4}$ to $10^{5} \mathrm{yr}$ (Milankovitch cycles) (Berger et al., 1989; Strasser, 1994; Husinec and Read, 2007). In this article, cycles from the depositional sequence to decimeter-scale rhythmic alternation of limestone and marl in the Ti-thonian outer-middle ramp succession of the Vaca Muerta Formation are studied, using a cyclostratigraphic approach. Interestingly, this stratigraphic interval is considered to be the most effective source rock in the Neuquén Basin (Mitchum and Uliana, 1985).

Cyclostratigraphic works on Tithonian successions are still scarce and mostly based on shallow-water carbonate environ-ments (Strasser, 1994; Husinec and Read, 2007). Additional Jurassic-Cretaceous examples are described by Weedon et al.(1999, 2004), Bádenas et al. (2003), Anderson (2004), and Strasser et al. (2004).

Cyclostratigraphic studies have been frequently used in the Northern Hemisphere but rarely applied to the Southern Hemisphere geologic record. Only a few works have dealt with this subject in Argentina (Sagasti, 2005; Scasso et al., 2005). Although the Vaca Muerta Formation indicates a great potential for cyclostratigraphic analysis, no detailed work has yet been conducted, despite the excellent existence of repet-itive succession of limestone-marlstone couplets throughout theentire basin.

The aim of this article includes the description and inter-pretation of the cyclicity of the Tithonian interval of the Vaca Muerta Formation. The cyclostratigraphic study is supported by a facies analysis and biostratigraphic data. The Late Jurassic-Early Cretaceous interval is a key time of global source rock development. The recognition of orbital cycles in the Vaca Muerta Formation should contribute to a better evaluation of the depositional controls influencing the most prolific source rock in the Neuquén Basin and a better characterization of the Late Jurassic-Early Cretaceous global climate.

\section{GEOLOGIC FRAMEWORK}

The Neuquén Basin was a back-arc basin located on the west-ern margin of the South American platform and limited by the magmatic arc to the west and by a tectonic foreland to the southeast (Howell et al., 2005) between a 36 and $40^{\circ} \mathrm{S}$ latitude (Figure 1A). 


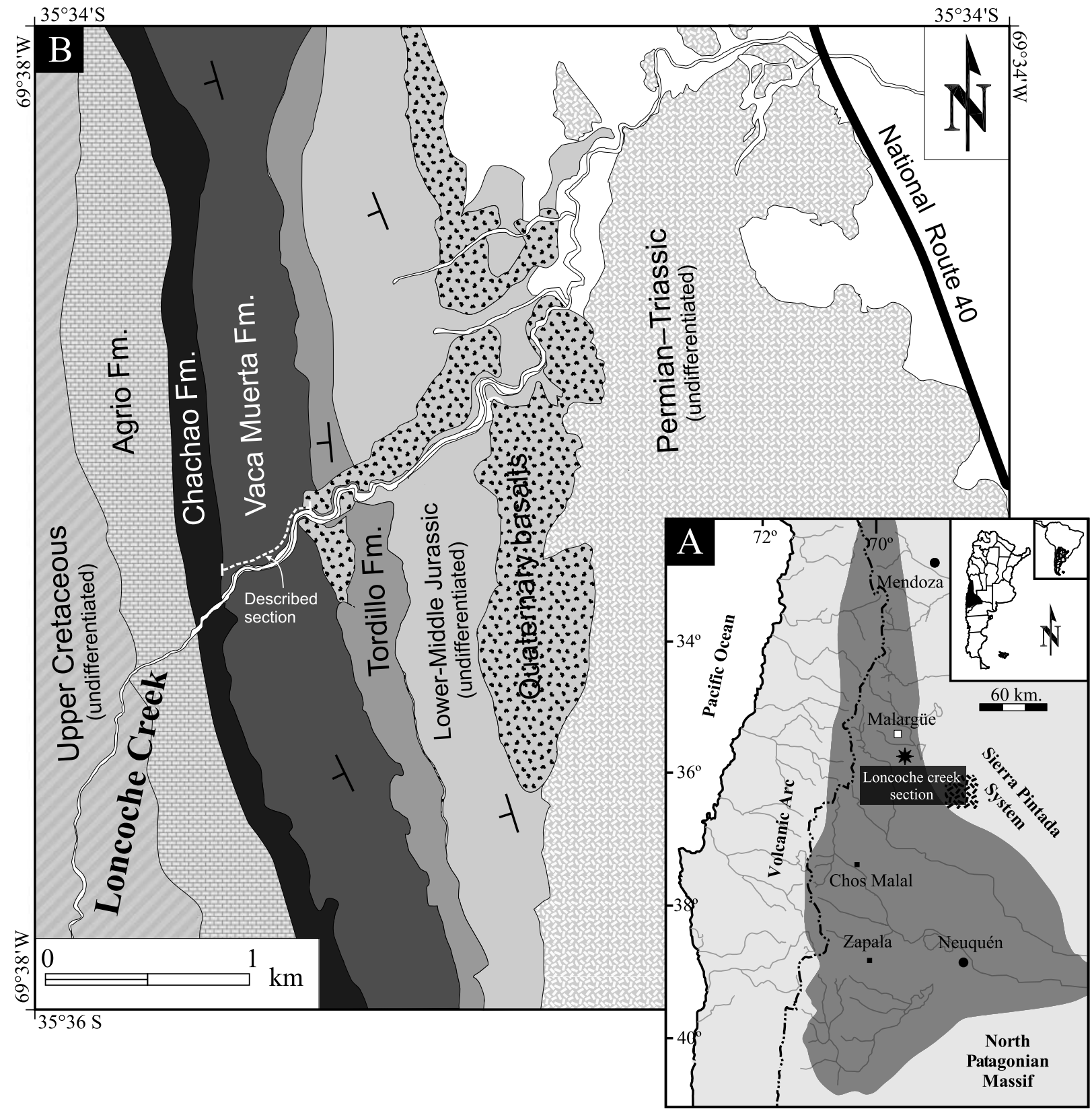

Figure 1. (A) Location map of the Neuquén Basin and the Loncoche section. (B) Geologic map of the study area (modified from Kietzmann et al., 2008).

The foreland consists of the Sierra Pintada belt to the northeast and the North Patagonian massif to the south. The base-ment consists of lower Paleozoic to Upper Triassic metamorphic, plutonic, and volcanic rocks. The Neuquén Basin has been interpreted as a retro-arc basin (Mitchum and Uliana, 1985; Legarreta and Uliana, 1991, among others). It is characterized by a very continuous Mesozoic and Cenozoic sedi-mentary record, comprising continental and ma-rine clastic, carbonate, and evaporitic deposits as much as $2600 \mathrm{~m}$ (8530 ft) thick. Marine incursions occurred at different time intervals through the connection with the Pacific Ocean (Legarreta and Uliana, 1991).

Legarreta and Gulisano (1989) described four tectonic episodes of basin development: (1) rifting 


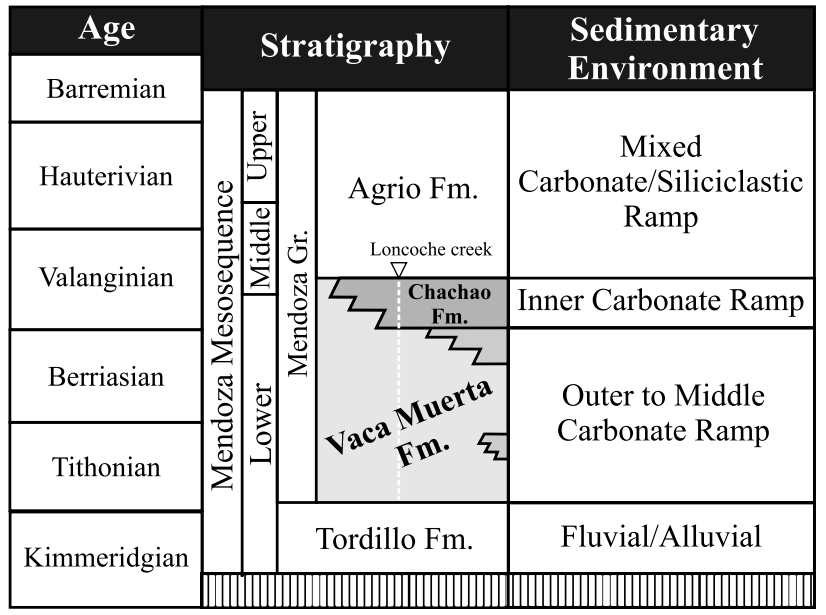

Figure 2. Stratigraphic chart for the Mendoza mesosequence of the Neuquén Basin, Mendoza province (data from Legarreta and Uliana, 1991).

(Late Triassic-Early Jurassic); (2) thermal subsidence (Early Jurassic-Late Cretaceous); (3) subsidence caused by loading (Late Cretaceous-Paleogene); and (4) Andean tectonism (Paleogene-early Quaternary).

The sequence-stratigraphic framework is based on seismic and outcrop data (Mitchum and Uliana, 1985; Legarreta and Gulisano, 1989; Legarreta and Uliana, 1991). Legarreta and Gulisano (1989) group all the Tithonian-Valanginian deposits of the Neuquén Basin into a broad shallowing-upward cycle (the lower Mendoza mesosequence, Figure 2), which was subdivided into nine depositional sequences. Legarreta and Uliana (1991) suggest a correlation between the depositional sequences with the global chart of third-order eustatic sea level variations (Haq et al., 1987). The Jurassic biostratigraphy is well defined based on ammo-nites and, to a lesser extent, on bivalves, brachio-pods, and microfossils, such as foraminifers, radio-larians, and calcareous nannofossils (Riccardi et al., 2000; Riccardi, 2008).

The lower Tithonian to lower Valanginian Vaca Muerta Formation is widely distributed throughout the Neuquén Basin. It consists of dark bituminous shales, marls, and limestones deposited in response to a rapid and widespread marine transgression originating from the Pacific Ocean, as a consequence of a tectonic phase of compressional relaxation (Legarreta and Uliana, 1991).
Previous works on this unit are abundant and cover sedimentologic, petrologic, and paleontologic aspects, as well as its economic importance for hydrocarbon exploration (Leanza, 1980; Uliana and Legarreta, 1993; Urien and Zambrano, 1994; Riccardi et al., 2000; Spalletti et al., 2000; Scasso et al., 2005; Kietzmann et al., 2008).

\section{STUDY AREA}

The studied area is located in the northern part of the Neuquén Basin, in the Mendoza province (Figure 1A). The measured section islocated $20 \mathrm{~km}$ (12 mi) south of the city of Malargüe, along the Loncoche Creek (Figure 1B). It exposes a 286-m (938-ft)-thick stratigraphic interval consisting of a homogeneous succession dominated by black shales, marls, and limestones, with a markedly cyclic aspect defined by the alternation of these lithologies at a decimeter scale. The age of the Vaca Muerta Formation in this section is early Tithonian to late Berriasian (Kietzmann et al., 2008). This study concentrates on the Tithonian part of the succession (Figure 3) because of its importance as a source rock interval, the excellent out-crop conditions, and the minor tectonic disruptions.

\section{METHODOLOGY}

A detailed sedimentologic section was measured and described bed by bed. Carbonate and siliciclastic lithofacies were analyzed considering bed geometry, lithology, sedimentary structures, and fossil content.

Cyclostratigraphic analysis is based on the differentiation of decimeter-scale couplets of carbonate lithofacies/siliciclastic lithofacies (herein termed "elementary cycles"). Lower frequencies are searched using spectral analysis with the software POWGRAF2 (Pardo-Igúzquiza and RodríguezTovar, 2004) by means of different methods: the fast Fourier transform (FFT), the smoothed periodogram method, and the Blackman-Tukey method. Advantages and limitations of the different mathematical procedures can be consulted in Pestiaux and Berger (1984) and Weedon (2003). 
A

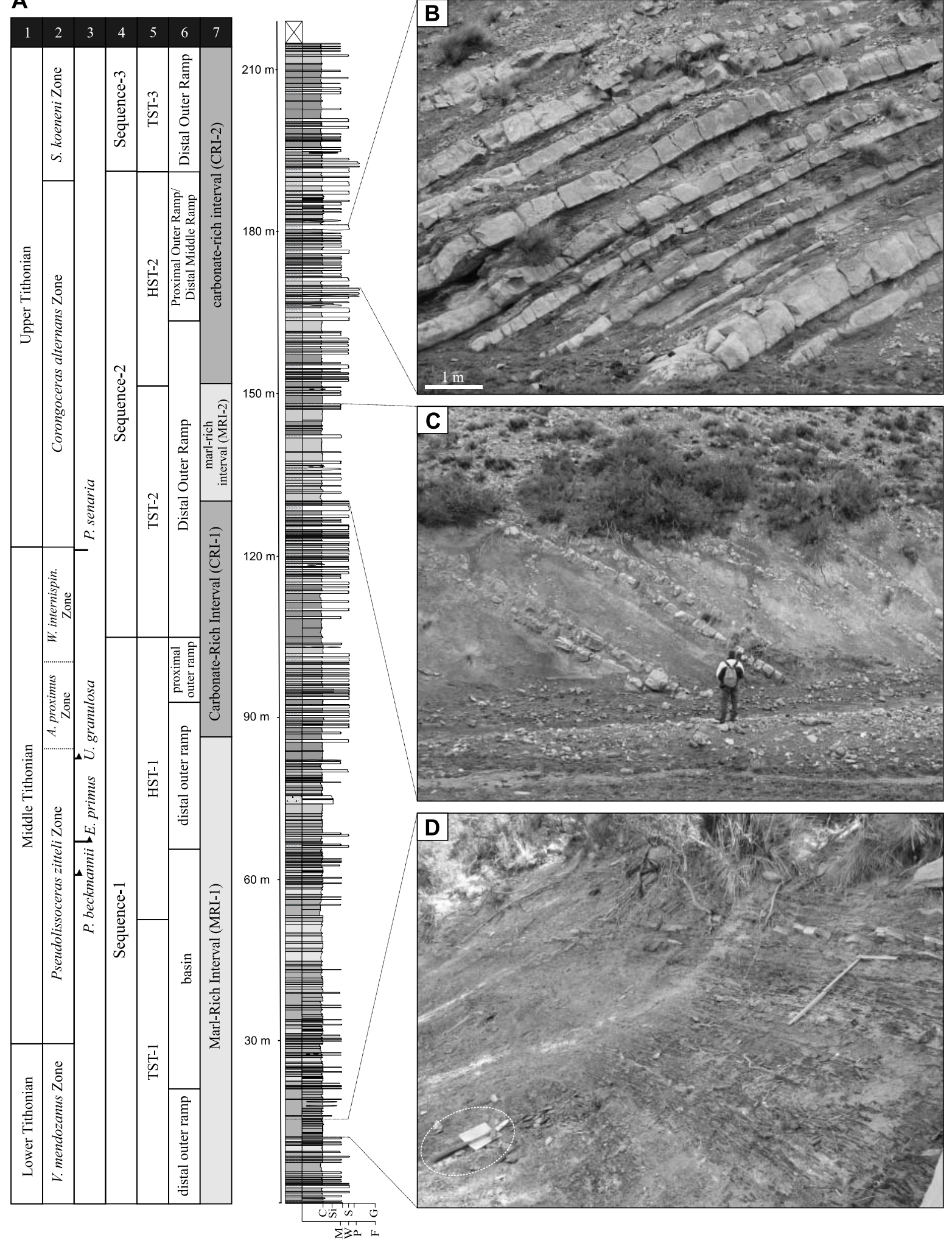

Figure 3. (A) Stratigraphic section of the Tithonian interval of the Vaca Muerta Formation in the Loncoche area, showing chronostratigraphic subdivision (1), ammonite biozones (2), nannofossil events (3), depositional sequences (4), systems tracts (5), depositional setting interpretation (6), and marl-rich and carbonate-rich intervals (7). (B) Carbonate-rich interval CRI-2 in the upper Tithonian section.(C) Marl-rich interval MRI-2 in the upper Tithonian section. (D) Black-shale-dominated interval without rhythmicity at the base of the Vaca Muerta Formation (lower Tithonian). 
Spectral analyses are based on the following basic premises: (1) The section consists of a succession of elementary cycles showing similar thicknessesalways within the range of several decimeters-that are considered to be similar in average duration. (2) Vertical changes in facies and bed thickness throughout the section could be related to periodic climate factors or to other nonperiodic factors as basin evolution. (3) Noncyclic intervals are not incorporated to the spectral analysis. These noncyclic intervals need to be considered for interpreting the long-term variations as well as for estimations of the total number of cycles in the stratigraphic section. An estimate of the number of hidden cycles was given by simply dividing their thicknesses by the average cycle thickness of the interval. With this approach, we got 251 cycles. (4) Sedimentation was essentially continuous through-out the studied time interval. This assumption is reasonable because field observations do not reveal any evidence of subaerial exposure, relevant ero-sional features, or condensed sedimentation.

To avoid possible effects of differential diagenetic compaction of different lithologies in the spectral calculations, all the statistical procedures were performed with both measured and decompacted thickness data. We have used the Baldwin (1971) factors for the backstripping approach.

\section{BIOCHRONOSTRATIGRAPHY}

The Tithonian interval of the Vaca Muerta Formation in the Loncoche Creek has been characterized by means of detailed ammonite and nannoplankton biostratigraphy (Figure 3), with the aim of getting a chronostratigraphic framework as robust as possible for the cyclostratigraphic analysis. According to Gradstein et al. (2004), the duration of the Tithonian stage is 5.3 m.y. The six Andean ammonite biozones of the Tithonian interval of the Neuquén Basin (Riccardi, 2008) and three calcareous nannofossil bioevents are recognized in the studied section (Figure 3). They include the first occurrences (FOs) of Polycostella beckmanii, Eiffellithus primus, Umbria granulosa, and the presence of Polycostella senaria.

\section{SEDIMENTARY FACIES}

In the Loncoche section, the Tithonian interval of the Vaca Muerta Formation consists of several facies (Table 1) that can be grouped into four main facies associations. These characterize different paleoenvironmental conditions and settings within a mid-outer carbonate ramp (e.g., Mitchum and Uliana, 1985).

\section{Facies Association I}

This facies association consists of laminated black shales rich in organic matter (as much as $6.6 \%$ ). It forms laterally persistent beds, decimeter to meter thick, with local occurrence of ellipsoidal carbonate concretions, commonly concentrated along strati-graphic horizons. The shale contains scarce fossils including ammonite fragments, oysters, infaunal bivalves, and fish scales.

Black shale intervals commonly alternate with decimeter-scale beds consisting of microbial mats (Figure 4A) with a conspicuous lamination defined by wavy to crinkly carbonaceous laminae and massive to laminated black to dark-gray lime mudstoneswackestones (Table 1). These carbonate intervals contain oysters, infaunal bivalves (Lucina neuquensis), ammonites, echinoderm fragments, benthic foraminifers (Epistomina sp.), and radiolarians (Figure 5A). Subordinately, this assemblage can include centimeter-scale beds of siltstones and fine-grained carbonate sandstones with smallscale rip-ple lamination (Table 1).

Sedimentation occurred in a landlocked restricted marine environment with anoxic bottom waters, below storm-wave base (basin to outer ramp setting), as indicated by the absence of waveinduced structures, and the benthic microbial activity coexisting with the passive accumulation of organic materials and pelagic microfossils. The high organic matter content suggests elevated organic productivity or good preservation, as well as the absence of bottom-dwelling organisms (Savrda and Bottjer, 1986).

Sedimentation occurred mainly from suspension. However, the presence of fine-grained ripple laminated carbonate sandstones, as well as bioclastic 
Table 1. Facies Chart and Interpretation of Depositional Environment

\begin{tabular}{|c|c|c|c|c|}
\hline Lithologies & Geometry/Thickness & Primary Grain Types/lchnofossils & Sedimentary Structures & Depositional Setting \\
\hline Black shales & Tabular geometry; $0.01-1 \mathrm{~m}$ in thickness & $\begin{array}{l}\text { Ammonite fragments, oysters, } \\
\text { former aragonitic bivalves }\end{array}$ & $\begin{array}{l}\text { Laminated or massive } \\
\text { Planar laminated or massive }\end{array}$ & $\begin{array}{l}\text { Basin to outer ramp setting. } \\
\text { Anoxic to dysaerobic conditions }\end{array}$ \\
\hline Brown shales & Tabular geometry; $2-80 \mathrm{~cm}$ in thickness & $\begin{array}{l}\text { Ammonites, small bivalves, oyster } \\
\text { fragments, radiolarian, forams. } \\
\text { Chondrites isp. }\end{array}$ & & $\begin{array}{l}\text { Outer ramp setting. Dysaerobic } \\
\text { to eventually aerobic conditions }\end{array}$ \\
\hline Siltstones & Tabular geometry; $10-80 \mathrm{~cm}$ in thickness & $\begin{array}{l}\text { Former aragonitic bivalves } \\
\text { (Lucina),oysters, fish scales }\end{array}$ & $\begin{array}{l}\text { Planar laminated; current ripple } \\
\text { lamination }\end{array}$ & $\begin{array}{l}\text { Outer ramp setting. Dysaerobic } \\
\text { to aerobic conditions Outer }\end{array}$ \\
\hline Marls & $\begin{array}{l}\text { Tabular geometry; } 2-380 \mathrm{~cm} \text { in thickness. } \\
\text { Interbedded with nodular mud wackestones }\end{array}$ & $\begin{array}{l}\text { Ammonite, serpulids, and bivalves. } \\
\text { Thalassinoides isp. }\end{array}$ & Thinly laminated & $\begin{array}{l}\text { to middle ramp setting. } \\
\text { Dysaerobic to aerobic conditions }\end{array}$ \\
\hline Mudstones-wackestones & $\begin{array}{l}\text { Tabular geometry; } 2-20 \mathrm{~cm} \text { in thickness } \\
\text { Interbedded with shales and marls }\end{array}$ & $\begin{array}{l}\text { Oysters, thin bivalves, ammonites, } \\
\text { radiolarian, and foraminifera }\end{array}$ & Planar laminated or massive & $\begin{array}{l}\text { Outer ramp setting. Anoxic to } \\
\text { dysaerobic conditions }\end{array}$ \\
\hline Bioclastic wackestones & $\begin{array}{l}\text { Tabular geometry to nodular; } 5-70 \\
\qquad \mathrm{~cm} \text { in thickness }\end{array}$ & $\begin{array}{l}\text { Ammonites, bivalves, oysters, } \\
\text { radiolarian, forams, gastropods, } \\
\text { and echinoderms. Thalassinoides, } \\
\text { Planolites, and Palaeophycus }\end{array}$ & Planar laminated or massive & $\begin{array}{l}\text { Outer to middle ramp setting. } \\
\text { Aerobic conditions }\end{array}$ \\
\hline Bioclastic packstones & $\begin{array}{l}\text { Tabular geometry to nodular; } 10-30 \mathrm{~cm} \text { in } \\
\text { thickness }\end{array}$ & $\begin{array}{l}\text { Ammonites, bivalves, oysters, } \\
\text { gastropods, echinoderms, and } \\
\text { serpulids. Phosphatized intraclasts } \\
\text { and peloids. Thalassinoides }\end{array}$ & Massive to planar laminated & $\begin{array}{l}\text { Outer to middle ramp setting. } \\
\text { Aerobic conditions }\end{array}$ \\
\hline
\end{tabular}


Figure 4. Sedimentary facies in the Loncoche

Creek section. (A) Black shales interbedded with laminated lime mudstones and microbial mats at the contact between the Vaca Muerta and Tordillo formations (dashed line).

(B) Concretional lime mudstones/wackestones interbedded with marls.

(C) Bioclastic

wackestones/packstones tempestite with an erosional contact and passive filling of Thalassinoides galleries (dashed line). (D)

Bioclastic wackestones with Tha-lassinoides (top bed view). Coin scale of $2.5 \mathrm{~cm}$ (0.98 in.)
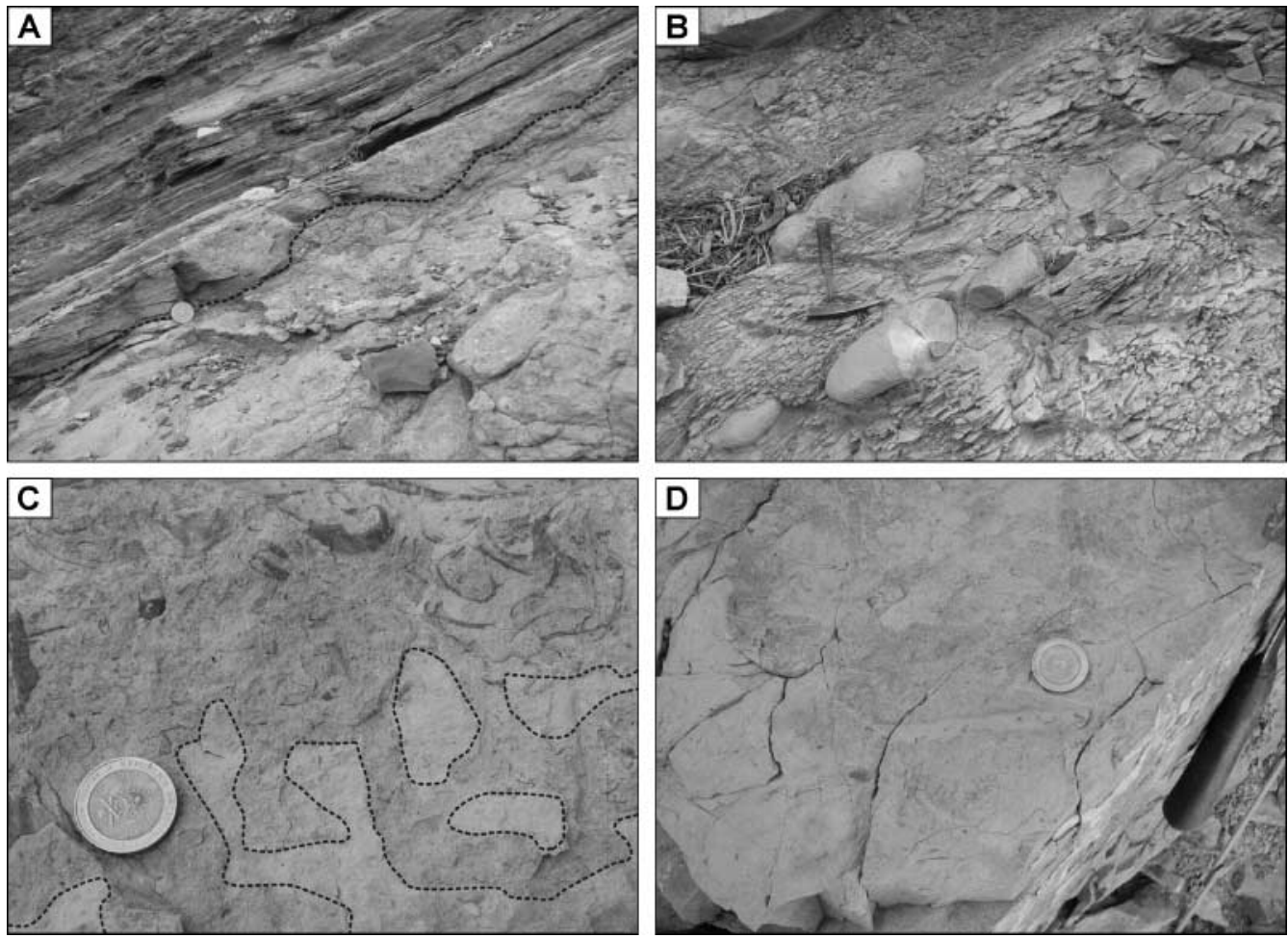

remains suchas in faunal bibalves and echiroderm fragments (bioclastic mudstone-wackestone), suggests shallow-water sediment input (Pittet and Strasser, 1998) probably associated with stormgenerated turbidite flows.

\section{Facies Association II}

This facies is defined by brown laminated shales, centimeter- to decimeter-scale thick, rhythmically alternating with (argillaceous) lime mudstoneswackestones. Shale beds contain transported infaunal bivalves and oyster fragments (Aetostreon sp.). Limestone beds are centimeter- to decimeter-scale thick, dark-gray, massive or laminated, bioclasticpeloidal mudstones-wackestones. Bioclasts include oyster (Aetostreon sp.), infaunal bivalves, echinoderms fragments, scarce brachiopods (Lingularia sp.), and ammonites. Microfossils are benthonic foraminifera (Epistomina sp.) and radiolarians (Figure 5B). Locally, some bioturbation represented by Chondrites can be present.

Horizontal lamination of the brown shales suggests that the deposition occurred in a low-energy environment, probably mostly from suspension. In contrast with the previous facies association, the sea bottom should have been dominantly dysaerobic, but eventually aerobic, as indicated by the sporadic presence of in-situ fauna remains. Chondrites traces are also considered typical of dysaerobic settings (Savrda and Bottjer, 1986).

Facies association II is interpreted as deposited in a dysaerobic outer ramp setting, dominated by fallout of fine muddy sediments. Bioclastic carbon-ate facies are probably produced by a combination of normal fallout of muddy sediments and suspended sediment transported during minor storms.

\section{Facies Association III}

This association is dominated by massive marls and bioclastic wackestones. The marls are laminated and olive gray, dark gray, or brown in color. They commonly yield horizontally arranged ammonites and bivalves. The latter include Aetostreon sp., Eriphyla sp., and Lucina neuquensis, which appear commonly disarticulated but rarely broken or abraded. Serpulids are also present (Rotularia sp.). The 
marls contain horizons of carbonate concretions (Figure 4B) and are moderately bioturbated, with rare Thalassinoides.

The bioclastic wackestones are black to dark gray and form massive or laminated beds. Bioturbation is common, with Thalassinoides (Figure 4C), Rhyzocorallium, a $\mathrm{n} d$ Palaeophycus. B i v a I v e s s u c $\mathrm{h}$ a $\mathrm{s}$ Ano-paea sp., Eriphyla sp., Lucina neuquensis, Cucullacea sp., and Aetostreon sp. are the dominant macrofossils. With the exception of the oysters, they are com-monly articulated. Breakage and abrasion are minor. Ammonites, small gastropods, serpulids (Rotularia sp.), echinoderm fragments, foraminifers (Epistomina sp.), and radiolarians are also present (Figure 5C, D). Nonskeletal components include fecal pellets and phosphatic particles.

Thin-bedded normal-graded bioclastic packstones-grainstones, typically with sharp bases, are intercalated within the other facies. They contain disarticulated and broken bivalves, ammonites and serpulid fragments, small gastropods, and foraminifers (Epistomina sp.).

Facies association III was probably deposited in a proximal outer ramp setting under moderately aerobic to dysaerobic conditions, below storm-wave base, as suggested by the bioclastic content, the generally good preservation state, occurrence of a benthonic community, and the moderately common bioturbation.

Marls and bioclastic wackestones represent fallout sedimentation during fair-weather conditions. Graded bioclastic packstones-grainstones with disarticulated and broken bioclasts, and sharp erosive bases, are interpreted as low-density tempestite flows originated by major storms.

\section{Facies Association IV}

This facies is defined by a higher abundance of carbonate. Decimeter-scale rhythmic changes in vertical facies successions are still recognizable. The dominant facies are dark-gray to gray-brown bioclastic wackestone-packstones, marly wackestones, and marls. Benthonic communities include epi- and infaunal bivalves, gastropods, echinoderms, and serpulids (Rotularia sp.). Among the bivalves, oysters are dominant (Aetostreon sp.), but others such as Grammatodon sp., Pholadomya sp., Eriphyla sp., and some pectinids are also common. Bivalves are generally articulated, with minor breakage and abrasion.

In some levels, oysters are aggregated to form biostromes that are up to several decimeters thick and have a conspicuous lateral continuity. Bioclastic levels show densely packed fabric and poor to moderate sorting. Oysters have convex-up, convexdown, nested, and/or random orientation. Nonskeletal components include phosphatized intraclasts and gastropods steinkerns (internal cast of gastropod cameras) (Figure 5F).

This facies association is characteristic of welloxygenated muddy bottoms commonly located in the middle ramp between the storm-wave base and the fair-weather wave base (Burchette and Wright, 1992). The development of oyster biostromes, with convex-up, convex-down, nested, and/or random shell orientation, is probably related to bottom remobilization occurring during major storms (Kietzmann and Palma, 2009; Kuhnt et al., 2009). Phosphatized intraclasts and steinkerns are typically associated with fluctuating sedimenta-tion rates and reworking and redepositional pro-cesses within the winnowing zone (Flügel, 2004). The coexistence of endobenthic (Grammatodon sp., Pholadomya sp., Eriphyla sp., and Thalassinoides isp.) and epibenthic organisms (gastropods, echi-noids, oysters, and pectinids) is also an evidence of alternating hydrodynamic and energy conditions (Kietzmann and Palma, 2009) that support this interpretation.

\section{Source Rock Characteristics}

Source beds of oil in the Vaca Muerta Formation occur in the Tithonian basal black shales that are considered to be the most effective source interval in the basin (Mitchum and Uliana, 1985).

Actually, more than $75 \%$ of the discovered hydrocarbons in Argentina were generated in Upper Jurassic and Lower Cretaceous source rocks, concomitant with rapid basinwide sea level rises (Uliana et al., 1999). Remaining reserves and production data associated with petroleum systems indicate that about $50 \%$ of hydrocarbons are from 
Figure 5. (A)

Radiolarian

wackestones $(R s=$ spumellarian; $R n=$

nassellar-ian). (B)

Wackestones with

Epistomina sp. (F) and

former aragonitic

bivalve fragments (B).

(C) Phos-phatic

wackestone with

aragonitic bivalve

fragments $(B)$,

phosphatized intra-clast

(Pi), phosphatized

peloids (Pp), and

terrige-nous particles

(T). (D) Bio-clastic

wackestones/

packstones with

formerly aragonitic

bivalve fragments,

gastropods (G), and

Epistomina sp. (F). (E)

Bio-clastic wackestone

with former aragonitic

bivalve fragments $(B)$,

oyster fragments (Bo),

serpulid fragments (S),

and terrige-nous

particles. (F) Bioclastic

wackestone with former

aragonitic bivalve

fragments $(B)$, oyster

fragments (Bo), and

sponge spicules $(\mathrm{Sp})$.

Scale $=1 \mathrm{~mm}$.
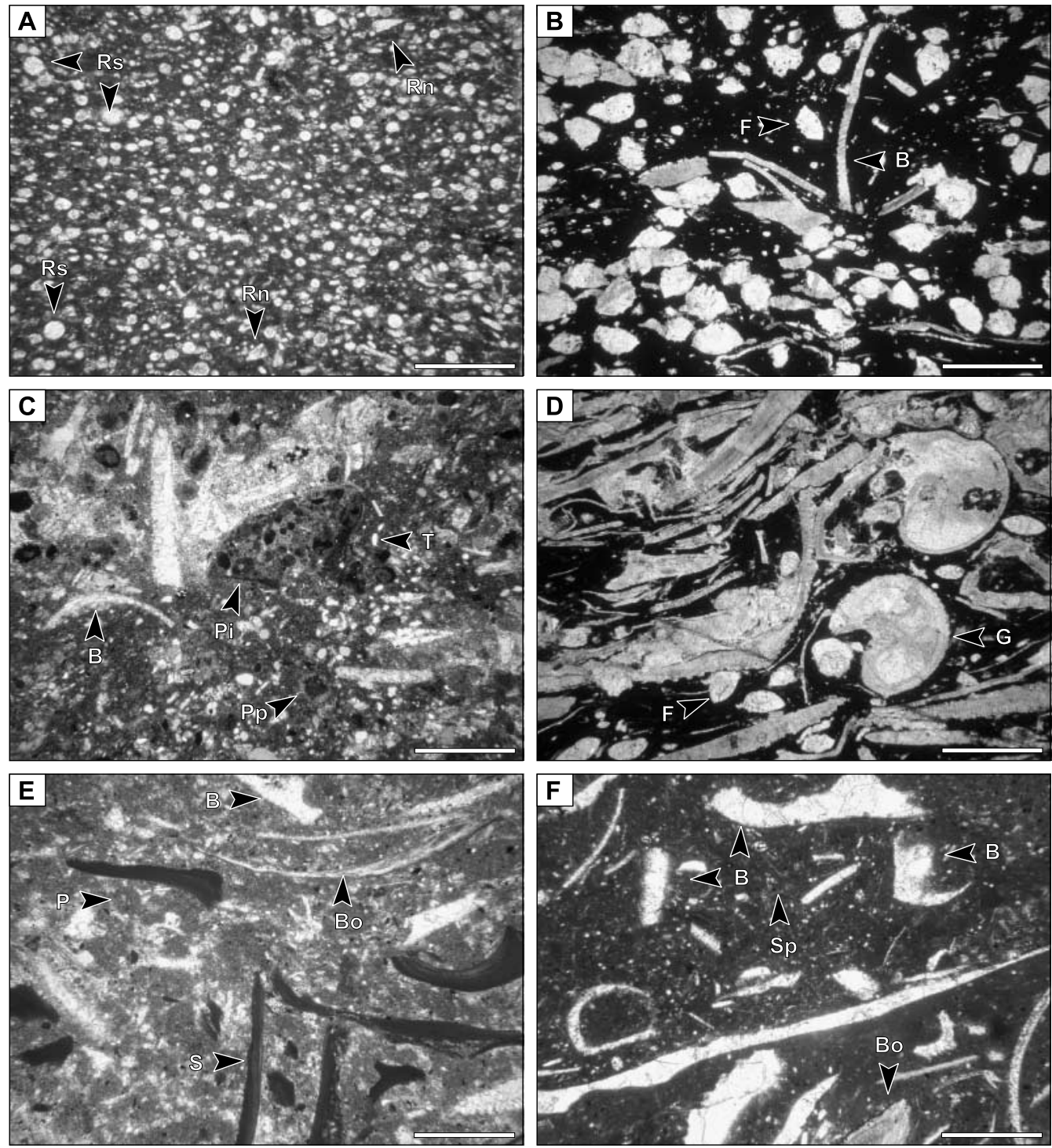

the Vaca Muerta Formation, which shows a prevalence of oil over gas (Legarreta et al., 2005).

These basal organic-rich deposits, that reach $50 \mathrm{~m}$ (164 ft) in thickness, occur in the Virgatosphinctes mendozanus zone up to the base of the Pseudolissoseras zitteli zone (Figure 3). Geochemical work toward the characterization of types and maturity of the organic matter in these levels through the basin shows that kerogen quality is remarkably homogeneous (Cruz et al., 1999). Organic matter richness in the black shales is variable, with total organic carbon (TOC) ranging between 3 and $8 \mathrm{vt}$. \% on average, althoug notably higher TOC contents, as much as 10 to $12 \mathrm{wt}$ \%, were also recognized (Villar et al., 1998). The visual kerogen analysis shows a predominance of amorphous organic matter, marine microplankton, and low participation of continental elements. Hydro-gen indices range from 400 to 800 (mg HC/g TOC), which indicate hydrogen-rich organic matter (types I-II kerogen) that qualifies these laminated black shale sequences as excellent oil-prone source rocks. Spectral data reported by Villar et al. (1998) showed that ions monitored had mass-to-charge ratios $(\mathrm{m} / \mathrm{z})$ of 191 for triterpanes and 217 for steranes. The hopane distribution is characterized by a regular progression of $\mathrm{C}_{29}$ to $\mathrm{C}_{34}$, suggesting anoxic conditions during deposition. In the $\mathrm{m} / \mathrm{z}$ 217 chromatogram, the $\mathrm{C}_{29}$ and $\mathrm{C}_{27}$ are the most predominant member series, pointing toward a 
continental origin (Palaces et al., 1984). Also, the degree of thermal evolution of the organic matter was evaluated by vitrinite reflectance. Data from the central area of the Neuquen Basin (Cruz et al., 2002) show that Vaca Muerta Formation is mostly in the oil-generation window.

\section{CYCLOSTRATIGRAPHIC ANALYSIS}

\section{Periodicity of Elementary Cycles and Spectral Analysis}

To establish the periodicity of the elementary cycles, the number of elementary cycles was divided by the total duration of the succession (251 cycles for 5.3 m.y.). The calculated average duration of each elementary cycle is $21.1 \mathrm{k} . \mathrm{y}$. This value is a good approximation to the average periodicity of the orbital precession, which according to astronomical models, is about 20 k.y. for the Late Jurassic (Berger et al., 1989). Data from other Jurassic examples are consistent with this average value (e.g., Hinnov and Park, 1999; Weedon et al., 1999; Husinec and Read, 2007).

Spectral analysis is applied to test the occurrence of Milankovitch cyclic elements of lower frequencies than the precessional elementary cycles using FFT periodogram, smoothed periodogram, and Blackman-Tukey estimators.

The FFT periodogram shows three peaks corresponding respectively to periods of 119,280 , and 597 k.y. within the $99 \%$ confidence limit. An additional peak at 86 k.y. more than $95 \%$ confidence limit is recognized. Peaks below 95\% confidence levels (e.g., 44 k.y.) were not considered (Figure 6B).

In the smoothed periodogram, the peaks identified are similar to those found using the FFT periodogram, with three main peaks at 87,119 , and 275 k.y. more than $95 \%$ confidence limit. A peak at 44 k.y. is also recognized, but because it is well below the $90 \%$ confidence limit, it was not taken into account (Figure 6C).

Finally, the Blackman-Tukey power spectrum shows two prominent peaks at 91 and 118 k.y. more than $95 \%$ confidence limit. A peak at 46 k.y. is also recognized, but it was not considered because its confidence level was less than 90\% (Figure 6D).

Both diagrams from compacted and decompacted thickness show peaks at frequencies of about $0.155,0.170$, and 0.194 , indicating relatively significant spectral peaks, with periods about 5.15 , 5.85 , and 6.38 times of duration for the elementary cycle. These peaks represent frequencies between 103 and 127 k.y. These results are consistent with the high-frequency components of the eccentricity cycle, which range between 90 and 120 k.y. (e.g., Weedon and Jenkyns, 1999; Weedon et al., 1999). In addition, we identify potential longer term oscil-lations, which are not coincident with the lowest components of the orbital-eccentricity cycle (413 k.y. and 1.3 m.y., Weedon and Jenkyns, 1999). Contrary to the length of the precession and obliquity cycles, which has become longer through the Phanerozoic, the periodicity of the eccentricity is thought to have remained stable (Berger et al., 1989; Laskar, 1999).

Diagenetic compaction could have notably altered the original cycle thickness. As compaction affects differentially clay-rich and carbonate-rich cycles, a bed-by-bed correction has been introduced in the procedure. The ratio between the initial depositional thickness and the measured presentday thickness is defined by the decompaction factor (Baldwin, 1971). The adopted values for decompaction factors for shallow to medium burial depth range from 1.2 for grain-supported carbonates, 2 to 2.5 for mud-dominated carbonates, and 3 for marls and shales. The results are summarized in the spectral diagrams of Figure 7.

\section{Main Genetic Intervals and Long-Term Cycles}

To avoid a specific genetic connotation, the Loncoche section is divided into four successive sedimentary intervals termed "marl-rich intervals" and "carbonate-rich intervals" according to the facies distribution (MRI-1, CRI-1, MRI-2, and CRI-2; see Figure 3).

MRI-1 is found at the lowermost part of the Vaca Muerta Formation and has a thickness of $47 \mathrm{~m}$ (154 ft). It is characterized by basin and distal-outer ramp facies, which show a clastic/limestone ratio of $4: 1$. Biostratigraphically, the interval MRI-1 covers the 


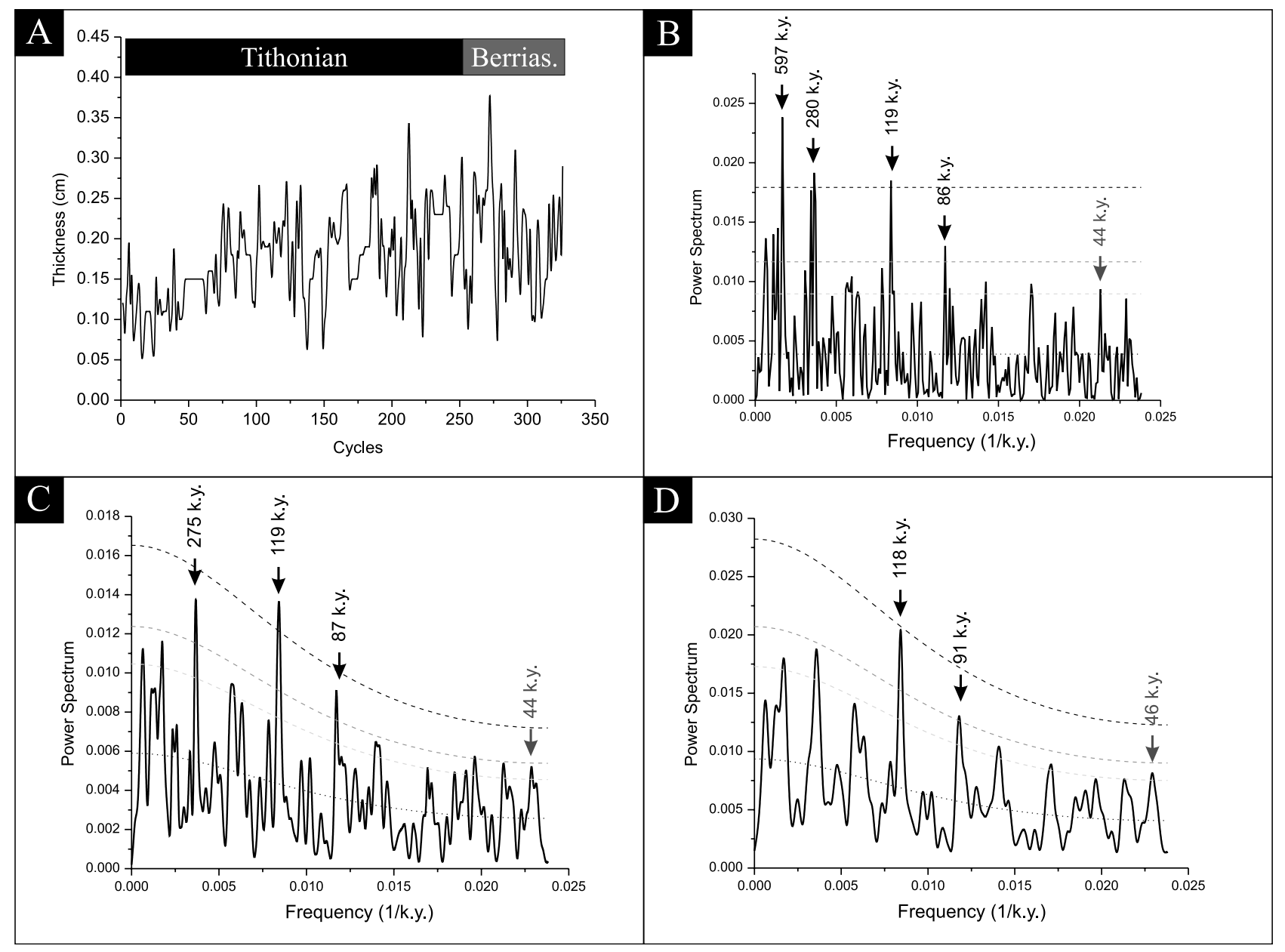

Figure 6. Cyclostratigraphic result of the Tithonian interval of the Vaca Muerta Formation. (A) Time series constructed with the precession elementary cycles. (B) Periodogram (fast Fourier transform) power spectrum without decompaction. (C) Smoothed peri-odogram power spectrum without decompaction. (D) Blackman-Tuckey power spectrum without decompaction.

Virgatophinctes mendozanus zone (lower Tithonian) and part of the Pseudolissoceras zitteli (lower part of the middle Tithonian) (Figure 3).

MRI-1 is composed of a relatively monotonous succession consisting of facies association I and, to a lesser extent, facies association II. This interval contains 56 elementary cycles. The cycles range in thickness from 0.15 to $0.90 \mathrm{~m}(0.49 \mathrm{t} 02.95 \mathrm{ft})$ with a mean of $0.4 \mathrm{~m}(1.3 \mathrm{ft})$. The basinal facies of the interval do not show a well-defined cyclicity.

CRI-1 is $57 \mathrm{~m}(187 \mathrm{ft})$ thick and characterized by distal outer ramp facies. The dominant facies associations are II and III. The clastic/limestone ratio approaches 1:1. The interval comprises the Pseudolissoceras zitteli zone (lowermost middle Tithonian) to the Windhauseniceras internispinosum zone (uppermost middle Tithonian).
This interval consists of 90 cycles. Elementary cycle thickness ranges from 0.12 to $1.25 \mathrm{~m}$ ( 0.39 to $4.1 \mathrm{ft})$, with a mean of $0.4 \mathrm{~m}(1.3 \mathrm{ft})$.

The MRI-2 is only $24 \mathrm{~m} \mathrm{(79} \mathrm{ft)} \mathrm{thick.} \mathrm{It} \mathrm{consists} \mathrm{of}$ an alternation of brown shale and marls with finegrained wackestones with a low faunal con-tend. These facies characterized an outer ramp setting and mostly correspond to facies association

\section{The clastic/limestone ratio is $3: 1$.}

This interval extends from the Windhauseniceras internispinosum zone (uppermost middle Tithonian) to the Corongoceras alternas zone (lowermost up-per Tithonian). It comprises 37 cycles (bed cou-ples). Cycle thickness ranges from 0.15 to $0.30 \mathrm{~m}$ (0.49 to $0.98 \mathrm{ft})$, with an average of $0.20 \mathrm{~m}(0.66 \mathrm{ft})$. CRI-2 is 45 $\mathrm{m}$ (148 ft) thick. It is composed of laminated brown marls and laminated to massive 


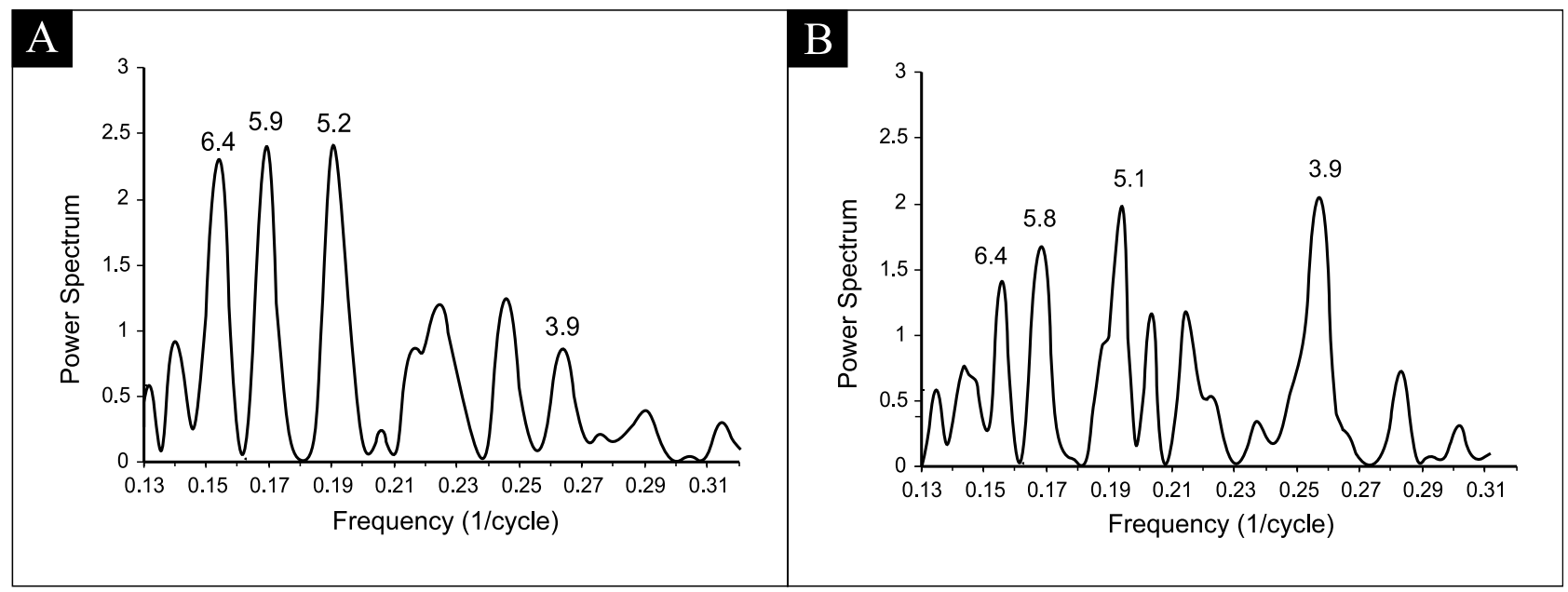

Figure 7. (A) Lomb-Scargle power spectrum without decompaction. (B) Lomb-Scargle power spectrum with decompaction.

bioclastic wackestones of facies association II and IV. The clastic/limestone ratio is $1: 1$. The time interval spans from the Corongoceras alternas zone (lowermost upper Tithonian) to the Substeueroceras koeneni zone (uppermost upper Tithonian). The elementary cycles are very well expressed and comprise 74 bed couples. The thickness of elementary cycles ranges from 0.12 to $0.97 \mathrm{~m}(0.39$ to $3.18 \mathrm{ft})$, with a mean of $0.4 \mathrm{~m}(1.3 \mathrm{ft})$.

\section{Interpretation}

Marl-limestone cycles have been cited as key examples of climate-forced sedimentation resulting from numerous paleoenvironmental factors, including fluctuations in the supply of calcareous biogenic sediments produced by plankton (productivity cycles, Einsele and Ricken, 1991) and fluctuations in the input of fine terrigenous sediments (dilution cycles, Arthur et al., 1984; Einsele and Ricken, 1991). Additional potential mechanisms include diagenetic redistribution of calcium carbonate (dissolution cycles, Einsele and Ricken, 1991; Westphal et al., 2010), fluctuations in carbonate mud export from shallow areas (carbonate dilution cycles, Pittet and Strasser, 1998), and fluctuations in superficial fertility (fertility cycles, Premoli Silva et al., 1989).

The four identified intervals in the studied section of the Vaca Muerta Formation can be inter- preted in terms of long-term changes of relative sea level and carbonate productivity. Using sequencestratigraphy data from Mitchum and Uliana (1985), Kietzmann et al. (2008), and Kietzmann and Palma (2009), the two marl-rich intervals can be attributed to transgressive episodes, as a consequence of a rapid rise of relative sea level. This process would explain low productivity in the surface waters a ndsh allow a reas a n d I o w oxyge natedsea bottom. By contrast, carbonate-rich intervals coincide with a decrease in accommodation, which induces an in-crease in carbonate basinward export from shal-lower areas and an increase in oxygenation of sea bottom.

The vertical patterns in cycle thickness outline the long-term changes in sedimentary accumulation rates, which are essentially coeval with the long-term variations in the carbonate productivity of shallow ramp areas. Cycles could be produced by changes in carbonate production in shallow areas, and these changes would be driven by orbitally induced climate changes (change in solar radiation).

Other Upper Jurassic-Lower Cretaceous examples (Weedon et al., 1999, 2004; Strasser, 1994; Bádenas et al., 2003; Anderson, 2004; Strasser et al., 2004; Husinec and Read, 2007) show a similar pattern, although the obliquity signal is thought to dominate at high latitudes and the precessional signal at middle and low latitudes (Weedon et al., 1999, 2004). 
Our analysis suggests that the elementary cycles of the Vaca Muerta Formation have an average duration of roughly 20 k.y. (precession) and are modulated by 100 k.y. (short-term eccentricity). Low-frequency orbital eccentricity and obliquity have not been identified in this study and seem to have minor importance. Therefore, our example is consistent with published data for similar latitudes in the Northern Hemisphere.

Cycles are probably driven by "carbonate dilution" processes, such as those described by Pittet and Strasser (1998), or by "carbonate exportation" processes proposed by Bádenas et al. (2003). These types of cycles are produced by changes in shallowwater carbonate production, which in turn involve changes in carbonate basinward exportation. Orbital variations induce climate changes by means of the control of solar radiation. This interpretation is supported by the dominance of storm-related processes, as well as the relative proportion of $\mathrm{C}_{2} 9$ over $\mathrm{C}_{27}$ steranes, which suggests some continental input for the organic matter.

\section{CONCLUSIONS}

The study interval of the Loncoche section comprises the early Tithonian Virgatosphinctes mendozanus zone to the late Tithonian Substeueroceras koeneni zone. Three calcareous nannofossil bioevents have been found. They include the first occurrences (FOs) of Polycostella beckmanii, Eiffellithus primus, Umbria granulosa, and the presence of Polycostella senaria. Four main facies associations reflect differ-ent paleoenvironmental conditions. Facies associa-tion I consists of black shales deposited under anoxic conditions below a storm-wave base. Facies association II consists of alternating brown laminated shales and lime mudstones-wackestones deposited in a dysaerobic to aerobic low-energy environment. Facies association III, dominated by marls and bioclastic wackestones, is characterized by higher contents in carbonates than the previous associations and was deposited in anaerobic outer ramp environment. Facies association IV is dominated by peloidal wackestones-packstones, oyster biostromes and marls.
This facies was deposited in well-oxygenated muddy bottoms located within the storm-wave base.

Three prominent frequencies were identified at 20 (precession), 90, and 120 k.y., respectively (eccentricity). Our analysis strongly suggests that the elementary cycles of the Vaca Muerta Formation were of roughly average duration and were probably formed by precessional-driven climate changes modulated by high-frequency eccentricity. We suggest that the precession orbital element was the main driver of periodic climate changes during the Late Jurassic in mid latitudes of the Southern Hemisphere. Climatic or paleoceanographic changes controlled by low-frequency orbital eccentricity seem to have lesser importance, and those controlled by the obliquity have not been identified in this study.

\section{REFERENCES CITED}

Anderson, E. J., 2004, The cyclic hierarchy of the "Purbeckian"

Sierra del Pozo section, Lower Cretaceous (Berriasian), southern Spain: Sedimentology, v. 51, p. 455-477, doi:10.1111/j.1365-3091.2004.00632.x.

Arthur, M. A., W. E. Dean, and D. A. V. Stow, 1984, Models for the deposition of Mesozoic fine-grained organic carbon-rich sediment in the deep sea, in D. A. V. Stow and D. J. W. Piper, eds., Fine-grained sediments: Deep-water processes and facies: Geological Society (London) Spe-cial Publication 15, p. 527-560.

Bádenas, B., M. Aurell, F. J. Rodríguez-Tovar, and E. PardoIgúzquiza, 2003, Sequence stratigraphy and bedding rhythms of an outer ramp limestone succession (late Kimmeridgian, northeast Spain): Sedimentary Geology,

v.161, p. 153 -174, doi:10.1016/S0037-0738(03) 00099-X

Baldwin, B., 1971, Ways of deciphering compacted sediments: Journal of Sedimentary Research, v. 41, p. 293301.

Berger, A., M. F. Loutre, and V. Dehant, 1989, Astronomical frequencies for pre-Quaternary paleoclimate studies: Terra Nova, v. 1, p. 474-479, doi:10.1111/ j.1365-3121 .1989.tb00413.x.

Burchette, T. P., and V. P. Wright, 1992, Carbonate ramp depositional systems: Sedimentary Geology, v. 79, p. 357, doi:10.1016/0037-0738(92)90003-A.

Cruz, C., E. Kozlowski, and H. J. Villar, 1999, Agrio (Neocomian) petroleum systems, main target in the Neuquén Basin thrust belt, Argentina: IV Congreso Exploración y Desarrollo de Hidrocarburos, Actas I, Mar del Plata,

p. 891-892. 
Cruz, C., A. Boll, R. Gómez Omil, E. Martínez, C. Arregui, C. Gulisano, G. Laffitte, and H. J. Villar, 2002, Hábitat de hidrocarburos y sistemas de carga Los Molles y Vaca Muerta en el sector central de la Cuenca Neuquina, Argentina: V Congreso de Exploración y Desarrollo de Hidrocarburos, Mar del Plata, IAPG, CD-ROM.

Einsele, G., and W. Ricken, 1991, Limestone-marl alternation: An overview, in G. Einsele, W. Ricken, and A. Seilacher, eds., Cycles and events in stratigraphy: Berlin-Heidelberg, Springer Verlag, p. 23-47.

Flügel, E., 2004, Microfacies of carbonate rocks, analysis, interpretation and application: Berlin-Heidelberg, Springer, $976 \mathrm{p}$.

Gradstein, F. M., J. G. Ogg, and A. G. Smith, 2004, A geologic time scale: Cambridge, Cambridge University Press, $589 \mathrm{p}$.

Haq, B. U., J. Hardenbol, and P. R. Vail, 1987, Chronology of fluctuating sea level since the Triassic: Science, v. 235, p. 1156-1167, doi:10.1126/science.235.4793.1156.

Hinnov, L. A., and J. J. Park, 1999, Strategies for assessing early Middle (Pliensbachian-Aalenian) Jurassic cyclochronologies: Royal Society, Philosophical Transactions: Mathematical, Physical and Engineering Sciences, v. 357, p. 1831-1859.

Howell, J. A., E. Schwarz, and L. A. Spalletti, 2005, The Neuquén Basin: An overview, in G. D. Veiga, L. A. Spalletti, J. A. Howell, and E. Schwarz, eds., The Neuquén Basin, Argentina: A case study in sequence stratigraphy and basin dynamics: Geological Society (London) Special Publication 252, p. 1-13.

Husinec, A., and J. F. Read, 2007, The Late Jurassic Tithonian, a greenhouse phase in the Middle Jurassic-Early Cretaceous "cool" mode: Evidence from the cyclic Adriatic platform, Croatia: Sedimentology, v. 54, p. 317-337, doi:10.1111/j.1365-3091.2006.00837.x.

Kietzmann, D. A., and R. M. Palma, 2009, Tafofacies y biofacies de Formación Vaca Muerta en el sector surmendoci-no de la Cuenca Neuquina: Implicancias paleoecológicas, sedimentológicas y estratigráficas: Ameghiniana, v. 46, p. 321-343.

Kietzmann, D. A., R. M. Palma, and G. S. Bressan, 2008, Facies y microfacies de la rampa tithoniana-berriasiana de la Cuenca Neuquina (Formación Vaca Muerta) en la sección del arroyo Loncoche-Malargüe, provincia de Mendoza: Revista de la Asociación Geológica Argentina, v. 63, p. 696-713.

Kuhnt, W., A. Holbourn, A. Gale, E. H. Chellai, and W. J. Kennedy, 2009, Cenomanian sequence stratigraphy and sea level fluctuations in the Tarfaya Basin (SW Morocco): Geological Society of America Bulletin, v. 121, p. 16951710, doi:10.1130/B26418.1.

Laskar, L., 1999, Astronomical calibration of OligoceneMiocene time: Royal Society of London Philosophical Transactions, v. 357, p. 1909-1927.

Leanza, H. A., 1980, The lower and middle Tithonian ammonite fauna from Cerro Lotena, province of Neuquén, Argentina: Zitteliana, v. 5, p. 3-49.

Legarreta, L., and C. A. Gulisano, 1989, Análisis estratigráfi-co secuencial de la Cuenca Neuquina (Triásico superior-Terciario inferior, Argentina), in G. Chebli and L. A.
Spalletti, eds., Cuencas Sedimentarias Argentinas: Universidad Nacional de Tucumán, Serie Correlación Geológica 6, p. 221-243.

Legarreta, L., and M. A. Uliana, 1991, Jurassic-Cretaceous marine oscillations and geometry of back-arc basin, cen-tral Argentina Andes, in D. I. M. McDonald, ed., Sea level changes at active plate margins: Process and product: Oxford, International Association of Sedimentologists Special Publication 12, p. 429-450.

Legarreta, L., H. J. Villar, G. A. Laffitte, C. E. Cruz, and G. Vergani, 2005, Cuenca Neuquina: Balance de masa enfocado a la evaluación del potencial exploratorio de los distritos productivos y de las zonas no productivas: VI Congreso de Exploración y Desarrollo de Hidrocarburos, p. 233-250.

Mitchum, R. M., and M. A. Uliana, 1985, Seismic stratigraphy of carbonate depositional sequences, Upper JurassicLower Cretaceous Neuquén Basin, Argentina, in R. B. Berg and D. G. Woolverton, eds., Seismic stratigraphy: An integrated approach to hydrocarbon exploration: AAPG Memoir 39, p. 255-274.

P a I a c e s, J.G., D

E. A n d e rs, a n d J.D.King, 1984 , S o u th Florida basin-prime example of carbonate source rocks of petroleum, in J. G. Palaces, ed., Petroleum geochem-istry and source rock potential of carbonate rocks: AAPG Studies in Geology 18, p. 71-96.

Pardo-Igúzquiza, E., and F. Rodríguez-Tovar, 2004, POWGRAF 2: A program for graphical spectral analysis in cyclostratigraphy: Computers and Geosciences, v. 30, p. 533-542, doi:10.1016/j.cageo.2004.03.004.

Pestiaux, P., and A. Berger, 1984, An optimal approach to the spectral characterization of deep-sea climate records, in A. Berger, J. Imbrie, G. Kukla, and B. Saltzman, eds., Milankovitch and climate: Dordrecht, D. Reidel, p. 417-445.

Pittet, B., and A. Strasser, 1998, Depositional sequences in deep-shelf environments formed through carbonate mud import from the shallow platform (late Oxfordian, German Swabian Alb and eastern Swiss Jura): Eclogae Geologicae Helvetiae, v. 91, p. 149-169.

Premoli Silva, I., E. Erba, and I. Tornaghi, 1989, Paleoenvironmental signals and changes in surface fertility in midCretaceous $\mathrm{C}$ org-rich facies of the fucoid marls (central Italy): Geobios, v. 11, p. 225-236, doi:10.1016/S0016 $-6995(89) 80059-2$.

Riccardi, A., 2008, El Jurásico de Argentina y sus Amonites: Revista de la Asociación Geológica Argentina, v. 63, p. 625-643.

Riccardi, A. C., H. A. Leanza, S. Damborenea, M. Manceñido, S. Ballent, and A. Zeiss, 2000, Marine Mesozoic biostratigraphy of the Neuquén Basin: 31st Internacional Geological Congress, Río de Janeiro, p. 103-108.

Sagasti, G., 2005, Hemipelagic record of orbitally induced di-lution cycles in Lower Cretaceous sediments of the Neu-quén Basin, in G. D. Veiga, L. A. Spalletti, J. A. Howell, and E. Schwarz, eds., The Neuquén Basin, Argentina: A case study in sequence stratigraphy and basin dynamics: Geological Society (London) Special Publication 252, p. 231-250.

Savrda, C. E., and D. J. Bottjer, 1986, Trace fossil model for 
reconstruction of paleo-oxygenation in bottom waters: Geology, v. 14, p. 3-6, doi:10.1130/0091-7613(1986) 14<3:TMFROP>2.0.CO;2.

Scasso, R. A., S. M. Alonso, S. Lanés, H. J. Villar, and H. Lippai, 2005, Geochemistry and petrology of a middle Tithonian limestone-marl rhythmite in the Neuquén Basin, Argentina: Depositional and burial history, in G. D. Veiga, L. A. Spalletti, J. A. Howell, and E. Schwarz, eds., The Neuquén Basin, Argentina: A case study in sequence stra-tigraphy and basin dynamics: Geological Society (Lon-don) Special Publication 252, p. 207-229.

Spalletti, L. A., J. R. Franzese, S. D. Matheos, and E. Schwarz, 2000, Sequence stratigraphy of a tidally domi-nated carbonate-siliciclastic ramp: The Tithonian-early Berriasian of the southern Neuquén Basin, Argentina: Geological Society (London) Special Publication 157, p. 433-446.

Strasser, A., 1994, Milankovitch cyclicity and high-resolution sequence stratigraphy in lagoonal-peritidal carbonates (upper Tithonian-lower Berriasian, French Jura Moun-tains), in P. L. de Boer and D. G. Smith, eds., Orbital forcing and cyclic sequences: Oxford, International Assso-ciation of Sedimentologists Special Publication 19, p. 285- 301.

Strasser, A., H. Hillgärtner, and J. B. Pasquier, 2004, Cyclostratigraphic timing of sedimentary processes: An exam-ple from the Berriasian of the Swiss and French Jura Mountains, in B. D'Argenio, A. G. Fischer, I. Premoli Silva, H. Weissert, and V. Ferreri, eds., Cyclostratigra-phy: Approaches and case histories: SEPM Special Pub-lication 81, p. 135-151.

Uliana, M. A., and L. Legarreta, 1993, Hydrocarbons habitat in a Triassic-to-Cretaceous sub-Andean setting: Neuquén Basin, Argentina: Journal of Petroleum Geology, v. 16,

p. 397-420, doi:10.1111/j.1747-5457.1993.tb00350.x.

Uliana, M. A., L. Legarreta, G. A. Laffite, and H. J. Villar,
1999, Estratigrafía y geoquímica de las facies generadoras de hidrocarburos en las cuencas petrolíferas de Argentina: IV Congreso Exploración y Desarrollo de Hidrocarburos, Actas I: p. 1-61.

Urien, C. M., and J. J. Zambrano, 1994, Petroleum systems in the Neuquén Basin, Argentina, in L. B. Magoon and W. G. Dow, eds., The petroleum system: From source to trap: AAPG Memoir 60, p. 513-534.

Villar, H. J., G. A. Laffite, and L. Legarreta, 1998, The source rocks of the Mesozoic petroleum systems of Argentina: A comparative overview on their geochemistry, paleoenvironments and hydrocarbon generation patterns (abs.): International Congress and Exhibition of the AAPG and the Brazilian Association of Petroleum Geologists, p. 186-187.

Weedon, G., 2003, Time-series analysis and cyclostratigraphy: Examining stratigraphic record of environmental cycles: New York, Cambridge University Press, 259 p.

Weedon, G. P., and H. C. Jenkyns, 1999, Cyclostratigraphy and the Early Jurassic time scale: Data from the Belemnite marls, Dorset, southern England: AAPG Bulletin, v. 111, p. $1823-1840$.

Weedon, G. P., H. C. Jenkyns, A. L. Coe, and S. P. Hesselbo, 1999, Astronomical calibration of the Jurassic time-scale from cyclostratigraphy in British mudrock formations: Philosophical Transactions: Mathematical, Physical and Engineering Sciences, v. 357, p. 1787-1813.

Weedon, G. P., A. L. Coe, and R. W. Gallois, 2004, Cyclostratigraphy, orbital tuning and inferred productivity for the type Kimmeridge clay (Late Jurassic), southern En-gland: Journal of the Geological Society, v. 161, p. 655-666, doi:10.1144/0016-764903-073.

Westphal, H., F. Hilgen, and A. Munnecke, 2010, An assessment of the suitability of individual rhythmic carbonate successions for astrochronological application: Earth-Science Reviews, v. 99, p. 19-30, doi:10.1016/j.earscirev .2010.02.001. 